\title{
NIE dla podziału Mazowsza - negatywne skutki planowanego podziału województwa mazowieckiego z perspektywy środowisk samorządowych, naukowych i mieszkańców ${ }^{1}$
}

\section{Paulina Żurawicka}

\section{STRESZCZENIE}

Od wielu lat okresowo dyskutowany jest zamiar podziału administracyjnego województwa mazowieckiego poprzez wyodrębnienie z niego województwa, obejmującego Warszawę i okoliczne powiaty. Dyskusja na ten temat uległa nasileniu w 2020 r. po wypowiedziach przedstawicieli partii rządzącej, zgodnie z którymi ww. podział miałby być przeprowadzony w $2021 \mathrm{r}$. W artykule przedstawiono najważniejsze negatywne konsekwencje planowanego podziału, wskazywane przez Samorząd Województwa Mazowieckiego i niezależnych autorów ze środowiska naukowego oraz zaprezentowano wyniki badania stanu wiedzy i opinii mieszkańców. Uwzględnione zostały również stanowiska w sprawie zachowania integralności województwa i powstrzymania planów jego podziału, przyjęte przez ponad 110 mazowieckich samorządów, instytucji i organizacji.

Słowa kluczowe: podział administracyjny, województwo mazowieckie

\section{Wstęp}

Jednym z celów ostatniej reformy administracyjnej Polski, która z dniem 1 stycznia 1999 r. wprowadziła trójstopniową strukturę podziału terytorialnego, było utworzenie silnych województw, będacych w stanie sprawnie realizować zadania własne i zlecone. Od tego czasu okresowo pojawiaja się propozycje zmian w ww. strukturze, w szczególności w odniesieniu do województwa mazowieckiego i wyodrębnienia z niego województwa warszawskiego stołecznego. Dyskusja na ten temat uległa nasileniu po wypowiedziach przedstawicieli par-

\footnotetext{
1 Artykuł powstał na podstawie Raportu z przeprowadzonego badania ankietowego dotyczącego planowanego podziału administracyjnego województwa mazowieckiego wraz z opracowaniem wyników tego badania.
}

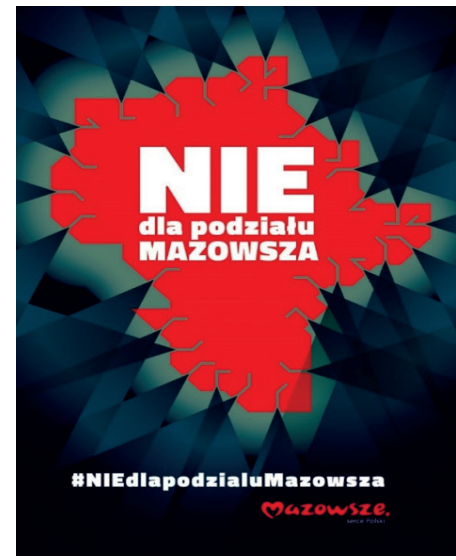

Ryc. 1. Plakat akcji informacyjnej "NIE dla podziału Mazowsza"

Źródło: Mazowsze Serce Polski, 2021, 13, 35, UMWM, Warszawa, s. 10 
tii rządzącej, zgodnie z którymi podział województwa zostanie przeprowadzony w $2021 \mathrm{r}$. Głównym argumentem, na który powołuje się strona rządowa uzasadniając koncepcję wydzielenia Warszawy i okolicznych powiatów, jest sprawiedliwsza niż dotychczas dystrybucja środków pomocowych w perspektywie finansowej Unii Europejskiej (UE) 2021-2027 i ich większa podaż dla uboższej części województwa mazowieckiego. Planowany podział miałby także służyć wzmocnieniu miasta lub miast, które stałyby się siedzibami władz województwa "pozawarszawskiego". Zapowiadany projekt ustawy w przedmiotowej sprawie nie został jeszcze przedstawiony opinii publicznej, w związku z tym nieznany jest planowany przebieg granic nowych województw - należy się spodziewać, że będzie on zgodny z obowiązującym od 2018 r. podziałem statystycznym na poziomie regionów (NUTS2). Przy takim założeniu nowe województwo stołeczne obejmowałoby region warszawski stołeczny (miasto Warszawa i 9 sassiadujących powiatów), a drugim województwem byłby otaczający je region mazowiecki regionalny.

W odpowiedzi na argumenty przytaczane przez zwolenników planowanego podziału administracyjnego, Samorząd Województwa Mazowieckiego przeprowadził szereg analiz, wykazujących nieracjonalność takiego podziału, w tym niekorzystne konsekwencje finansowe. Argumenty przeciwko podziałowi Mazowsza przedstawiło także środowisko naukowe. Ponadto ponad 110 mazowieckich samorządów, instytucji i organizacji ${ }^{2}$ przyjęło stanowisko w sprawie zachowania integralności województwa i powstrzymania planów jego podziału. Zdaniem oponentów dotychczas nie pojawiły się poważne argumenty, przemawiające za planowanym podziałem województwa.

Ze względu na to, że organizacja terytorialna państwa oddziałuje na rozwój społecznogospodarczy całego kraju i poszczególnych regionów, warunkuje efektywność działania administracji publicznej oraz kształtuje ramy prowadzenia polityki regionalnej i lokalnej, istotne zmiany jej struktury powinny zostać poprzedzone konsultacjami społecznymi i przebiegać zgodnie z obowiązującymi przepisami prawa. Jak podkreślają samorządy ${ }^{3}$, konsekwencje podziału województwa wpłynęłyby przede wszystkim na mieszkańców, dlatego tak poważna decyzja nie może zostać podjęta bez ich udziału.

W związku z powyższym, w celu poznania stanu wiedzy i opinii mieszkańców województwa mazowieckiego na temat proponowanych przez partię rządząca zmian administracyjnych, Marszałek Województwa Mazowieckiego powierzył wykonanie badania opinii publicznej Mazowieckiemu Biuru Planowania Regionalnego w Warszawie, realizującemu m.in. zadania samorządu województwa z zakresu rozwoju regionalnego. Przedmiotowe badanie przeprowadzone zostało na przełomie października i listopada $2020 \mathrm{r}$.

Celem artykułu jest przedstawienie opinii na temat negatywnych skutków podziału województwa mazowieckiego na podstawie analiz i stanowisk samorządowców, środowiska

\footnotetext{
${ }^{2}$ W tym m.in.: Wojewódzka Rada Dialogu Społecznego, Rada ds. Unii Europejskiej, Zarząd Związku Województw Rzeczypospolitej Polskiej, Zarząd Związku Miast Polskich, Mazowieckie Forum Terytorialne, Stowarzyszenie „Metropolia Warszawska”, rady miast: Ciechanowa, Płocka i Ostrołęki.

${ }^{3}$ https: / / www.mazovia.pl/aktualnosci/art,8245,skutki-ewentualnego-podzialu-mazowsza.html [dostęp: 22.02.2021 r.].
} 
naukowego oraz prezentacja wyników badania ankietowego, przeprowadzonego wśród mieszkańców.

\section{Polityka rozwoju prowadzona przez Samorząd Województwa Mazowieckiego}

Województwo mazowieckie jest największym, zarówno pod względem zajmowanej powierzchni jak i liczby ludności, województwem w kraju. Obejmuje obszar o powierzchni 35,6 tys. km², stanowiący 11,4\% powierzchni kraju, który w 2019 r. zamieszkiwało 5423,2 tys. osób - tj. 14,1\% ludności Polski [BDL, stan na 2019 r.]. Mazowsze charakteryzuje się wysokim tempem wzrostu gospodarczego i największym - 22,8\% udziałem w generowaniu Produktu Krajowego Brutto (PKB) [Wstępne szacunki ... 2020], jednocześnie będąc województwem najbardziej zróżnicowanym wewnętrznie pod względem społeczno-gospodarczym. Motorem rozwoju mazowieckiej gospodarki jest przede wszystkim Warszawa ze swoim otoczeniem. PKB w regionie warszawskim stołecznym w przeliczeniu na jednego mieszkańca - w porównaniu ze średnią krajową - wyniósł w 2019 r. 219,7\% [Wstępne szacunki ... 2020], co stanowi $160 \%{ }^{4}$ średniej UE, podczas gdy w pozostałej części województwa wskaźniki te wynosza odpowiednio: 86,4\% [Wstępne szacunki ... 2020] i 63\%5.

Samorząd Województwa Mazowieckiego od początku funkcjonowania prowadzi politykę rozwoju, której głównym celem jest zmniejszenie dysproporcji rozwoju w województwie i wzrost znaczenia Obszaru Metropolitalnego Warszawy w Europie [Strategia rozwoju ... 2013]. W efekcie prowadzonej polityki równoważenia rozwoju, m.in. poprzez preferencyjny dla uboższych peryferii województwa podział środków unijnych w ramach kolejnych edycji regionalnego programu operacyjnego, pozametropolitalna część województwa coraz lepiej się rozwija.

Ze względu na to, że podstawowym kryterium przyznania środków finansowych UE dla poszczególnych regionów, określonych we wspólnej Klasyfikacji Jednostek Terytorialnych do Celów Statystycznych (NUTS), jest wartość PKB na jednego mieszkańca, Samorząd Województwa Mazowieckiego od wielu lat zabiegał o statystyczne wydzielenie Warszawy i okolicznych powiatów, w celu umożliwienia pozostałej, słabiej rozwiniętej części województwa uzyskania wyższego dofinansowania z programów unijnych. Taka możliwość pojawiła się dopiero w perspektywie 2021-2027, gdyż 1 stycznia 2018 r. weszło w życie rozporządzenie Komisji Europejskiej [Rozporządzenie Komisji ... 2016], zgodnie z którym województwo mazowieckie, funkcjonujace wcześniej jako jeden region, jest makroregionem NUTS 1, składającym się z dwóch regionów NUTS2: warszawskiego stołecznego (obejmującego Warszawę z dziewięcioma sąsiadującymi powiatami) oraz mazowieckiego regionalnego (obejmującego pozostałą część województwa). Wprowadzony podział statystyczny województwa mazowieckiego umożliwił zakwalifikowanie obu jego regionów do różnych kategorii zamożności

\footnotetext{
${ }^{4}$ Eurostat, Gross domestic product (GDP) at current market prices by NUTS 2 regions, unit of measure: purchasing power standard (PPS), per inhabitant in percentage of the EU27 average [dostęp: 22.03.2021 r.]. 5 Tamże.
} 
oraz dostosowanie wysokości i rodzaju wsparcia do ich potrzeb i potencjałów. Region warszawski stołeczny jest zaliczony do lepiej rozwiniętych regionów UE, natomiast mazowiecki regionalny - do słabiej rozwiniętych. Zgodnie z projektem Umowy Partnerstwa [Projekt Umowy ... 2021] w perspektywie 2021-2027 w województwie mazowieckim realizowany będzie jeden wspólny program regionalny z budżetem w wysokości 1,6 mld euro ${ }^{6}$, przy czym kwota ta zostanie rozdysponowana $\mathrm{z}$ uwzględnieniem różnego poziomu rozwoju dwóch regionów statystycznych - wstępnie ok. 1,5 mld euro dla mazowieckiego regionalnego i ok. 111,5 mln euro dla warszawskiego stołecznego. Beneficjenci z regionu mazowieckiego regionalnego będą mogli otrzymać dofinansowanie kosztów projektów w wysokości nawet 85\%, podczas gdy w minionej perspektywie finansowej wysokość dofinansowania w województwie mazowieckim wynosiła maksymalnie $80 \%$.

W celu uzyskania dodatkowego wsparcia z funduszy UE dla pozametropolitalnych części województwa, Samorząd Województwa Mazowieckiego od kilkunastu lat ${ }^{7}$ zabiegał o ich objeccie krajowym programem operacyjnym dla Polski Wschodniej. Dopiero pod koniec 2020 r., w związku z dokonanym w 2018 r. podziałem statystycznym, zapadła pozytywna decyzja strony rządowej w sprawie włączenia regionu mazowieckiego regionalnego do Programu Polska Wschodnia Plus na rozpoczynająca się perspektywę finansowa. Dzięki takiemu rozwiązaniu ten region otrzyma dodatkowe środki z budżetu UE (szacunkowo ok. $418 \mathrm{mln}$ euro), co znacznie zwiększy możliwości jego dalszego wzrostu gospodarczego.

\section{Negatywne skutki planowanego podziału administracyjnego województwa mazowieckiego w analizach środowiska samorządowego i naukowego}

Na potrzeby niniejszego artykułu przeanalizowano stanowiska samorządów, instytucji i organizacji w sprawie zachowania integralności województwa mazowieckiego oraz opinie środowiska naukowego nt. negatywnych konsekwencji podziału administracyjnego, planowanego przez partię rządzącą. W wielu stanowiskach zwrócono uwagę przede wszystkim na brak merytorycznych argumentów, przemawiających za podziałem oraz konieczność przeprowadzenia konsultacji z mieszkańcami województwa mazowieckiego oraz samorządami funkcjonujaccymi na jego terenie.

Jak podkreślają samorządowcy, w tym m.in. Rada Miasta Płock i Rada Miasta Mińsk Mazowiecki, administracyjny podział województwa wiąże się z koniecznością ustanowienia podwójnej administracji samorządowej i rządowej poziomu regionalnego (powstaną m.in. dwa urzędy wojewódzkie, dwa urzędy marszałkowskie, dwa sejmiki, podwójne służby podległe wojewodzie i marszałkowi, m.in.: inspekcja transportu drogowego, straż pożarna, inspekcja handlowa, sanitarna, służby weterynaryjne, inspekcja ochrony środowiska). Wzrost kosztów

\footnotetext{
${ }^{6}$ https: / / www.funduszedlamazowsza.eu/aktualnosci / fundusze-europejskie-dla-mazowsza-na-lata-2021-2027/ [dostęp: 19.02.2021 r.].

7 https: / / www.mazovia.pl/ dla-mediow / informacje-prasowe/ art,5021, mazowsze-w-polsce-wschodniej-stolica-i-70-gmin-poza-wsparciem-z-rpo-nowe-decyzje-rzadu.html [dostęp: 19.02.2021 r.].
} 
administracyjnych związanych z utworzeniem, a następnie utrzymaniem podwójnej struktury organizacyjnej, wpłynie na ograniczenie możliwości wydatkowych w innych sektorach.

Podział administracyjny województwa oznacza podział jego zadań, zadłużenia, wydatków i dochodów. Wśród komentatorów tej propozycji wyrażane są obawy co do tego, jak zostałby przeprowadzony podział długu województwa mazowieckiego, który obecnie wynosi ok. 800 mln zł [Mazowsze Serce ... 2020], np. dzieląc zadłużenie proporcjonalnie do liczby ludności, $43 \%$ tej kwoty przypadłoby do spłaty województwu regionalnemu.

Głównym źródłem dochodów Samorządu Województwa Mazowieckiego są wpływy z podatku dochodowego od osób prawnych (CIT) [Budżety jednostek ... 2019]. Mimo iż w 2019 r. co piąty podmiot gospodarki narodowej w krajowym rejestrze REGON zarejestrowany był w województwie mazowieckim [Podmioty gospodarki ... 2019], to ponad 3/4 podmiotów w województwie zarejestrowanych było w regionie warszawskim stołecznym [BDL, stan na 2019 r.]. Z szacunków urzędu marszałkowskiego wynika, że firmy z regionu mazowieckiego regionalnego, obejmującego $86 \%$ powierzchni obecnego województwa, generują tylko $13 \%{ }^{8}$ wpływów z CIT, zasilających budżet województwa. Wyłączenie administracyjne regionu warszawskiego stołecznego doprowadzi do tego, że pozostała część województwa będzie miała znacznie ograniczone dochody - budżet województwa pozametropolitalnego wynosiłby ok. 500 mln zł (dla porównania - w 2019 r. z budżetu województwa mazowieckiego do regionu mazowieckiego regionalnego trafiło 1,65 mld zł) [Mazowsze Serce ... 2020]. Taki stan rzeczy nie pozostanie bez wpływu na finansowanie inwestycji i realizację zadań publicznych, tym bardziej, że redukcja dochodów nie wiąże się z analogicznie zmniejszonym zakresem zadań i obowiązków. W regionie mazowieckim regionalnym siedzibę ma połowa ${ }^{10}$ wojewódzkich samorządowych jednostek organizacyjnych, takich jak: szpitale, instytucje kultury, biblioteki, centra kształcenia, spółki kolejowe. Zagrożona będzie realizacja zaplanowanych wieloletnich inwestycji, finansowanych z budżetu Samorządu Województwa Mazowieckiego, jak np. budowa Centrum Radioterapii w Płocku o wartości 80 mln zł ${ }^{11}$. Niemożliwe byłoby więc utrzymanie na obecnym poziomie usług publicznych dostarczanych mieszkańcom województwa mazowieckiego regionalnego.

Dynamiczne tempo wzrostu gospodarczego obecnego województwa mazowieckiego i wysokie dochody podatkowe mają wpływ na wysokość tzw. „janosikowego". Zgodnie z Wieloletnia Prognoza Finansowa Województwa Mazowieckiego na lata 2021-2038, wpłata na rzecz budżetu państwa z przeznaczeniem na część regionalną subwencji ogólnej wyniesie w $2021 \mathrm{r}$. $638,8 \mathrm{mln}$ zł. Uwzględniając obecnie obowiązujące zasady wyliczania, gdzie wysokość wpłaty jest uzależniona od poziomu wpływów podatkowych osiagniętych dwa lata wcześniej, plano-

\footnotetext{
${ }^{8}$ https: / / www.mazovia.pl/ dla-mediow / informacje-prasowe/ art,4924,podzial-wojewodztwa-zniszczy-mazowsze.html [dostęp 23.02.2021 r.].

${ }^{9}$ https: / / www.mazovia.pl/aktualnosci/art,8513,plock-przeciwny-podzialowi-wojewodztwa.html [dostęp: 23.02.2021 r.].

${ }^{10}$ https: / / www.mazovia.pl / aktualnosci / art,8186,podzial-wojewodztwa-zniszczy-mazowsze.html [dostęp: 23.02.2021 r.].

${ }^{11}$ https: / / www.mazovia.pl/aktualnosci/art,8513,plock-przeciwny-podzialowi-wojewodztwa.html [dostęp: 01.03.2021 r.].
} 
wany podział administracyjny oznaczałby dla nowego województwa warszawskiego stołecznego, wzrost „janosikowego" o ok. $180 \mathrm{mln}$ zł rocznie [Mazowsze Serce ... 2021].

Zmiana granic administracyjnych spowoduje podział wielu podmiotów działających w obszarze całego województwa, w tym m.in. Agencji Rozwoju Mazowsza, Kolei Mazowieckich, Mazowieckiej Agencji Energetycznej, Mazowieckiego Funduszu Poręczeń Kredytowych. W przypadku Kolei Mazowieckich - spółki Samorządu Województwa Mazowieckiego, będącej głównym organizatorem przewozów kolejowych na terenie województwa - zdaniem ekspertów ${ }^{12}$ podział województwa może skutkować spadkiem jakości świadczonych usług. Najbardziej rentowne połączenia realizowane są na terenie aglomeracji warszawskiej, gdzie wpływy ze sprzedaży biletów pokrywają większość ponoszonych kosztów, dlatego też zapotrzebowanie na dodatkowe środki z budżetu nowego województwa stołecznego byłoby minimalne. Natomiast po reorganizacji spółki, połączenia na liniach deficytowych, wymagających największego dofinansowania, przypadna głównie województwu mazowieckiemu regionalnemu, co w konsekwencji może oznaczać ich ograniczenie lub nawet likwidację [Swianiewicz 2016]. Dotyczy to połączeń na liniach znajdujących się w największej odległości od stolicy, takich jak np. Siedlce-Łuków, Sierpc-Płock oraz dojazdy do aglomeracji warszawskiej z najbardziej oddalonych obszarów - Dęblina, Siedlec, Radomia, Małkini itd. Zgodnie z Wieloletnia Prognoza Finansowa Województwa Mazowieckiego na lata 2021-2038, na dofinansowanie działalności przewozowej spółki Koleje Mazowieckie Samorząd Województwa Mazowieckiego zamierza tylko w 2021 r. przeznaczyć ok. 393 mln zł.

W opinii ekspertów [Swianiewicz 2016] podział administracyjny stwarza ryzyko pogłębienia dysproporcji rozwojowych pomiędzy nowo utworzonymi województwami - warszawskim stołecznym a mazowieckim regionalnym. Utrudniona będzie koordynacja polityki regionalnej i polityk sektorowych (transportowej, służby zdrowia, rynku pracy) w odniesieniu do całego obszaru. Polityka rozwoju będzie prowadzona przez dwa odrębne, niezależne od siebie samorządy, których działalność będzie nastawiona na rozwój i aktywizację swoich obszarów oraz budowanie własnych potencjałów i marek. Jednak równomierny rozwój Mazowsza wymaga synchronizacji działań podejmowanych zarówno w stosunku do aglomeracji warszawskiej, jak i jego obszarów peryferyjnych. Nie będzie to możliwe, gdy strategie rozwoju obydwu województw będą powstawały oddzielnie i niezależnie od siebie. Nastąpi ograniczenie pozytywnego oddziaływania Warszawy na rozwój wydzielonego województwa regionalnego, co przy jego niewielkim budżecie doprowadzi do zwiększenia dystansu rozwojowego obydwu regionów.

Kształtowanie przy ograniczonych środkach finansowych nowej stolicy/stolic województwa mazowieckiego regionalnego (najprawdopodobniej w ośrodkach o znaczeniu regionalnym: Radomiu lub/i w Płocku), kwestionuje politykę rozwoju dla ośrodków subregionalnych: Siedlec, Ciechanowa, Ostrołęki, a także mniejszych miast i terenów wiejskich. Pomysłodawcy podziału Mazowsza są zdania, że konieczność rozwoju struktury organiza-

12 https:/ / www.polityka.pl/tygodnikpolityka/ kraj/1982378,1, podzial-mazowsza-warszawa-zyskaobwarzanek-straci.read [dostęp: 23.02.2021 r.]. 
cyjnej nowo utworzonego województwa mazowieckiego regionalnego, w tym siedziby jego władz, będzie impulsem rozwojowym dla miasta lub miast, którym zostana powierzone funkcje stołeczne. Powołuja się m.in. na efekty reformy administracyjnej Polski z 1975 r., wprowadzającej podział kraju na 49 województw (utworzono m.in. województwa: siedleckie, ciechanowskie, ostrołęckie i radomskie), po której miasta, którym powierzono funkcje stołeczne nowych województw, zaczęły się dynamicznie rozwijać. Eksperci ze środowisk naukowych podkreślają jednak, że rozwój ten nastąpił w innych niż obecnie warunkach gospodarczych i politycznych - gospodarki centralnie planowanej, gdzie decyzje gospodarcze podejmowane były przez władze centralne, a udział kapitału prywatnego był minimalny. Utracie statusów miast wojewódzkich w 1998 r. towarzyszyły inne niekorzystne procesy, $\mathrm{w}$ tym transformacja gospodarcza $\mathrm{w}$ latach 90 . i spowolnienie gospodarcze $\mathrm{z}$ przełomu XX i XXI w. ${ }^{13}$ Z przeprowadzonej przez ekspertów z Uniwersytetu Warszawskiego porównawczej analizy wskaźnikowej ${ }^{14}$ byłych miast wojewódzkich z miastami zbliżonymi wielkościowo, które do dzisiaj pozostały stolicami województw, wynika, że trend zmian w obydwu grupach miast był podobny (w badaniu zestawiano zmiany liczby ludności, dochody z podatków od przedsiębiorstw, bezrobocie i przyrost powierzchni nieruchomości komercyjnych). Zdaniem badaczy [Swianiewicz 2016] znaczenie funkcji stołecznej bywa przeceniane. Nierealne jest więc oczekiwanie, że odzyskanie pozycji stolicy województwa np. przez Radom, samoczynnie rozwiąże problemy tego miasta.

W opinii samorządowców ${ }^{15}$ podział administracyjny województwa mazowieckiego na obecnym etapie planowania budżetu UE na lata 2021-2027 spowoduje opóźnienia we wdrażaniu środków przeznaczonych na tę perspektywę, nie tylko na poziomie regionalnym, ale także na poziomie całego kraju. Po podziale opracowane do tej pory dokumenty i ustalenia wynegocjowane z Komisją Europejską będą wymagały istotnych zmian. Dla nowych województw oznacza to m.in. konieczność opracowania i negocjacji odrębnych regionalnych programów operacyjnych. Opóźnienie w uruchomieniu unijnego wsparcia, umożliwiającego pobudzenie gospodarki w dobie kryzysu wywołanego pandemią COVID-19, byłoby bardzo niekorzystne.

Przeciwko nieprzemyślanym i niekonsultowanym społecznie zmianom administracyjnym należy także przedstawić stanowisko Rady UE, która w zaleceniach w sprawie krajowego programu reform Polski na 2020 r. podkreśliła, kluczowe dla zapewnienia wzrostu gospodarczego kraju, znaczenie stabilności systemu instytucjonalnego i systemu prawa, a także zaufania do jakości i przewidywalności polityki i instytucji regulacyjnych oraz zwróciła uwagę na pogorszenie jakości dialogu społecznego w Polsce [Zalecenie Rady ... 2020].

\footnotetext{
${ }^{13}$ https: / / regiony.rp.pl/ dyskusje/34065-komu-i-po-co-potrzebny-jest-podzial-mazowsza [dostęp: 23.02.2021 r.].

${ }_{14}$ Tamże.

15 Stanowisko Zarządu Związku Województw Rzeczypospolitej Polskiej z dnia 3 sierpnia 2020 r. w sprawie zapowiedzi administracyjnego podziału województwa mazowieckiego.
} 


\section{Wyniki badania opinii publicznej}

Kwestionariusz badania ankietowego został przygotowany przez Mazowieckie Biuro Planowania Regionalnego w Warszawie. Z 1050 osób, które wzięły udział w badaniu, 250 było mieszkańcami regionu warszawskiego stołecznego, a pozostałe 800 - regionu mazowieckiego regionalnego. Wśród ankietowanych było więcej kobiet (54,3\%) niż mężczyzn, a najliczniejszą (28\%) grupa wiekową były osoby mające 35-44 lata.

Badanie wykazało, że większość respondentów (63\%) jest przeciwna planowanemu podziałowi województwa mazowieckiego na dwa nowe województwa,19,5\% nie ma zdania na ten temat. Za przedmiotowym podziałem opowiedziało się jedynie 17,5\% ankietowanych. Udział osób przeciwnych podziałowi województwa był porównywalnie wysoki w obydwu regionach.

Blisko 30\% respondentów nie wiedziało o planowanym przez partię rządząca podziale województwa - brak wiedzy zgłaszali najcześciej (40\%) najmłodsi badani, tj. w wieku 18-24 lata. Głównym źródłem informacji ankietowanych na ten temat była telewizja (53\%) i Internet $(45 \%)$.Telewizję najczęściej wskazywali badani w wieku $45+(66 \%)$, a Internet - osoby od 25 do 44 roku życia (69\%). Wielu ankietowanych mieszkańców województwa nie wiedziało, w którym nowym województwie (po planowanym podziale) znajdzie się ich gmina (30\% wszystkich respondentów, 63\% z regionu warszawskiego stołecznego). Ponadto $94 \%$ badanych wskazało, że nie ma wiedzy na temat obowiązującego od 2018 r. podziału województwa na dwa regiony statystyczne i związana z tym możliwość zróżnicowanego i optymalnego korzystania z funduszy UE w obecnym układzie administracyjnym. Mieszkańcy oczekuja konsultacji społecznych ws. propozycji podziału województwa i szczegółowej analizy ekspertów (ok. $54 \%$ badanych).

W opinii badanych największą wadą ewentualnego podziału województwa będzie nadmiernie rozbudowana biurokracja - 83\% respondentów wskazało, że nie akceptuje kosztów utworzenia i utrzymania osobnej administracji rządowej i samorządowej dla obu nowo wydzielonych województw. Ponadto wyniki badania wskazuja, że większość respondentów (95\%) uważa, że podział administracyjny województwa nie przyniesie poprawy oferty przewozów kolejowych realizowanych przez spółkę Koleje Mazowieckie (83\% wskazało, że nic się nie zmieni, 12\% wyraziło obawę, że oferta się pogorszy). W opinii większości ankietowanych $(86 \%)$ podział województwa mazowieckiego nie przyniesie pozytywnych zmian również w zakresie dostępności i jakości usług publicznych (76\% stwierdziło, że nic się nie zmieni, $10 \%$, że sytuacja się pogorszy). 


\section{Podsumowanie i wnioski}

Ewentualny podział administracyjny województwa mazowieckiego wymaga przygotowania spójnej koncepcji i głębokiego uzasadnienia merytorycznego ${ }^{16}$, tymczasem w medialnej dyskusji na ten temat, zarówno przez środowiska samorządowe, jak i niezależnych ekspertów wysuwane są poważne obawy, co do jego zasadności i przyszłych negatywnych skutków.

W opinii komentatorów planowany podział województwa przyniesie szereg negatywnych skutków społeczno-gospodarczych, szczególnie w obszarze planowanego województwa mazowieckiego regionalnego. Województwo to zostanie pozbawione potencjału do generowania dochodów na poziomie wystarczającym do realizacji ustawowych zadań - zdaniem ekspertów ${ }^{17}$ niemożliwe będzie utrzymanie na obecnym poziomie usług publicznych, a tym bardziej ich rozbudowa lub poprawa jakości. Planowany podział administracyjny spowoduje także znaczne opóźnienia we wdrażaniu środków z perspektywy finansowej UE 2021-2027, ze względu na konieczność opracowania i negocjacji dwóch odrębnych regionalnych programów operacyjnych.

Główny argument pomysłodawców podziału administracyjnego województwa, dotyczący zwiększenia dostępu do funduszy UE dla pozametropolitalnej części województwa, jest nieaktualny od początku 2018 r., tj. od momentu, w którym zaczął obowiązywać podział statystyczny województwa mazowieckiego na dwa regiony NUTS2. Wysokość środków finansowych, przyznanych $\mathrm{w}$ ramach regionalnych programów operacyjnych, uzależniona jest od poziomu rozwoju obu regionów, niezależnie od ich przynależności administracyjnej. W celu objęcia dodatkowym wsparciem z UE regionu mazowieckiego regionalnego, Samorząd Województwa Mazowieckiego zabiegał o jego włączenie do krajowego programu skierowanego do Polski Wschodniej, na co strona rządowa wyraziła zgodę pod koniec $2020 \mathrm{r}$.

Analizy ekspertów dyskredytują także kolejny, przytaczany przez zwolenników podziału administracyjnego argument, dotyczacy wzmocnienia miasta lub miast, które po podziale stałyby się siedzibami nowych władz wojewódzkich. Przedmiotowe badania wykazały, że automatycznego, pozytywnego wpływu statusu stolicy regionu na rozwój miasta nie należy traktować jako oczywistości, podobnie jak tego, że odzyskanie takiego statusu, utraconego w 1999 r., samoistnie rozwiąże problemy Radomia lub innych miast.

Badanie ankietowe przeprowadzone wśród mieszkańców Mazowsza wykazało, że większość z nich jest przeciwna planowanemu podziałowi. Ponadto blisko połowa respondentów nie wiedziała, w którym nowym województwie (po planowanym podziale) będzie położona ich gmina. Ponad $90 \%$ osób objętych badaniem nie było także świadomych obowiązującego podziału statystycznego województwa mazowieckiego, pozwalającego na zróżnicowane, optymalne korzystanie z funduszy UE w obecnym układzie administracyjnym.

\footnotetext{
${ }^{16}$ https:/ / regiony.rp.pl/sponsorowane/33967-nie-dzielmy-mazowsza-budujmy-i-integrujmy [dostęp: 23.02.2021 r.].

17 https: / / regiony.rp.pl / dyskusje / 34065-komu-i-po-co-potrzebny-jest-podzial-mazowsza [dostęp: 23.02.2021 r.].
} 
Wszelkie działania dotyczace tak poważnej ingerencji w podział administracyjny kraju, powinny być przeprowadzone z poszanowaniem opinii i woli zainteresowanych mieszkańców, co znajduje potwierdzenie w wynikach badania ankietowego - większość respondentów uważa, że propozycja podziału Mazowsza powinna być poddana konsultacjom społecznym i szczegółowej analizie ekspertów.

\section{Literatura}

Budżety jednostek samorzadu terytorialnego w województwie mazowieckim w 2019 r., 2020, GUS, Warszawa.

Mazowsze Serce Polski, 2021, 13, 35, Urząd Marszałkowski Województwa Mazowieckiego, Warszawa, s. 4-11.

Mazowsze Serce Polski, 2020, 9, 31, Urząd Marszałkowski Województwa Mazowieckiego, Warszawa s. 5-16.

Podmioty gospodarki narodowej w rejestrze REGON w województwie mazowieckim. Stan na koniec 2019 r., 2020, GUS, Warszawa.

Projekt Umowy Partnerstwa dla realizacji Polityki Spójności 2021-2027 w Polsce, 2021, Ministerstwo Funduszy i Polityki Regionalnej, Warszawa.

Raport z badania ankietowego ws. planowanego podziału administracyjnego województwa mazowieckiego przygotowany dla Mazowieckiego Biura Planowania Regionalnego w Warszawie.

Rozporządzenie Komisji (UE) 2016/2066 z dnia 21 listopada 2016 r. zmieniające załączniki do rozporządzenia (WE) nr 1059/ 2003 Parlamentu Europejskiego i Rady w sprawie ustalenia wspólnej klasyfikacji Jednostek Terytorialnych do Celów Statystycznych (NUTS).

Stanowiska samorządów, instytucji i organizacji ws. zachowania integralności województwa mazowieckiego.

Strategia Rozwoju Województwa Mazowieckiego do 2030 roku. Innowacyjne Mazowsze, Uchwała nr 158/13 Sejmiku Województwa Mazowieckiego z dnia 28 października 2013 r.

Swianiewicz P., 2016, Podziat województwa mazowieckiego - błąd społeczny i ekonomiczny? Materiały pokonferencyjne, Urząd Marszałkowski Województwa Mazowieckiego, Warszawa.

Wieloletnia Prognoza Finansowa Województwa Mazowieckiego na lata 2021-2038, Uchwała 173/ 20 Sejmiku Województwa Mazowieckiego z dnia 15 grudnia 2020 r.

Wstępne szacunki produktu krajowego brutto w przekroju regionów w 2019 r., 2020, GUS, Warszawa.

Zalecenie Rady w sprawie krajowego programu reform Polski na 2020 r. oraz zawierające opinię Rady na temat przedstawionego przez Polskę programu konwergencji na 2020 r., $\operatorname{COM}(2020) 521$ final. 


\section{Strony internetowe}

https: / / bdl.stat.gov.pl/BDL/ start [dostęp: 19.02.2021 r.]

https: / / ec.europa.eu/ eurostat [dostęp: 22.03.2021 r.]

https: / / regiony.rp.pl/ dyskusje/34065-komu-i-po-co-potrzebny-jest-podzial-mazowsza [dostęp: 23.02.2021 r.]

https: / / regiony.rp.pl / sponsorowane/33967-nie-dzielmy-mazowsza-budujmy-i-integrujmy [dostęp 23.02.2021 r.]

https: / / www.funduszedlamazowsza.eu / aktualnosci / fundusze-europejskie-dla-mazowsza-na-lata-2021-2027 [dostęp 19.02.2021 r.]

https: / / www.mazovia.pl/ aktualnosci/art,8186,podzial-wojewodztwa-zniszczy-mazowsze. html [dostęp: 23.02.2021 r.]

https: / / www.mazovia.pl / aktualnosci/ art,8513,plock-przeciwny-podzialowi-wojewodztwa.html [dostęp: 23.02.2021 r.]

https: / / www.mazovia.pl / dla-mediow / informacje-prasowe / art,4924,podzial-wojewodztwa-zniszczy-mazowsze.html [dostęp 23.02.2021 r.]

https: / / www.mazovia.pl / dla-mediow / informacje-prasowe/ art,4953,skutki-ewentualnego-podzialu-mazowsza.html [dostęp: 22.02.2021 r.]

https: / / www.mazovia.pl / dla-mediow / informacje-prasowe / art,5021,mazowsze-w-polsce-wschodniej-stolica-i-70-gmin-poza-wsparciem-z-rpo-nowe-decyzje-rzadu.html [dostęp: 19.02.2021 r.]

https: / / www.polityka.pl/tygodnikpolityka/ kraj/1982378,1,podzial-mazowsza-warszawazyska-obwarzanek-straci.read [dostęp: 23.02.2021 r.] 


\section{NO to the partition of Mazovia - negative effects of the planned partition of the region from the perspective of the local and regional government, the scientific community and the inhabitants}

\section{ABSTRACT}

Over the years, there have been recurrent discussions of the administrative division of the Mazovia Region by separating Warsaw and the neighboring counties. The discussion has intensified in 2020 after the representatives of the ruling political party declared that the division would be carried out in 2021 . The article presents the most important negative consequences of the planned division, as indicated by the Regional Government of Mazovia and independent authors from the scientific community. It also shows the results of research on the inhabitants' knowledge and opinion. Also taken into account were the positions on preserving the integrity of the region and preventing its division, adopted by over 110 local governments, institutions and organizations.

Key words: administrative division, Mazovia Region

Paulina Żurawicka - absolwentka Szkoły Głównej Gospodarstwa Wiejskiego w Warszawie, pracownik samorządowy, kontakt: Mazowieckie Biuro Planowania Regionalnego w Warszawie, Oddział Terenowy w Siedlcach, ul. Pułaskiego 19/21, 08-110 Siedlce, e-mail: pzurawicka@mbpr.pl

Paulina Żurawicka - graduate of Warsaw University of Life Sciences in the field of spatial management; regional government employee, contact: Mazovian Office for Regional Planning in Warsaw, Branch office in Siedlce, ul. Pułaskiego 19/21, 08-110 Siedlce, e-mail: pzurawicka@mbpr.pl 